\title{
Os mundos íntimos do soleil
}

\author{
Béatrice Picon-Vallin
}

Nós estamos no círculo - nós somos afetados. O Coro, na sua roda, desenha o círculo humano. Escandindo o ritmo que nos lembra: Você também, você também (Hélène Cixous, sobre os Atrides). ${ }^{1}$

$\checkmark$

á mais de quarenta anos a trupe internacional do Théâtre du Soleil procura dar conta do presente. Estar no presente: é isso que a cena, que deve assumir esse tempo na representação, tem, no entanto, dificuldade em assegurar, diante do cinema, que parece mais habilitado para se apoderar dos temas atuais. Conforme afirmou Matthias Langhoff, "Mede-se a força de um período teatral pela rapidez da sua reação àquilo que o cerca. ${ }^{2}$ Pode-se medir a força do Soleil segundo esse critério. La ville parjure em 1994 tratava do escândalo do sangue contaminado, bem antes que a televisão ousasse abordá-lo. Em 1997 com Et soudain des nuits d'éveil, o Théâtre du Soleil, "essa casa do presente", ${ }^{3}$ abordava, através da ficção e da magia distanciada dos rituais tibetanos dançados, um dos mais graves problemas do século que viria, o dos exilados, dos refugiados, dos sem-papéis, e a aventura da solidariedade do "viver juntos", para aprofundá-lo, em 2003, em uma nova forma teatral, um teatro documentário repensado: Le dernier caravansérail. Tratava-se de um mega-espetáculo, construído a partir de improvisaçóes coletivas e de entrevistas gravadas, de testemunhos, de palavras transmitidas em versão original e em tradução projetada por um teatro-viajante que, desde a sua fundação recolhe mundo afora a matéria e a forma de suas obras.

\section{Encontrar a distância adequada}

Para Ariane Mnouchkine, que detém as rédeas dessa aventura teatral e humana - radical, exigente, impiedosa e generosa ao mesmo tempo, que repousa mais no reconhecimento do público, do que no da crítica ou dos "pares" - tratase de praticar uma arte necessária, descobrindo

Béatrice Picon-Vallin é diretora de pesquisas do Centro Nacional de Pesquisa Científica (CNRS) da França e professora da Universidade Paris III - Sorbonne nouvelle. Tradução de Maria Lúcia de Souza Barros Pupo.

1 Ciclo de espetáculos do Soleil, 1990-1992.

2 Jornal Libération, 4 de abril de 1995.

3 H. Cixous, "Un moment de conversion" no programa de Et soudain des nuits d'éveil. 
meios sempre renovados para dar conta teatralmente do estado do mundo e do nosso estado, nesse mundo presente. Trata-se de encontrar ângulos adequados de abordagem, de medir e estabelecer distâncias variáveis, de experimentar diferentes modalidades possíveis para compor um dispositivo de criação teatral em vários níveis, capaz de desvelar, de explorar todas as facetas do contemporâneo: mitos (Les Atrides), grande História próxima e geografia distante (Sihanouk, L'Indiade), narrativas distantes e orientalizadas (os Shakespeare), pequena história teatral e tragédia de uma nação (ocupação de um teatro e aniquilamento do povo tibetano de Et soudain les nuits d'éveil). A cada vez portanto, uma distância é introduzida, e ela nunca é a mesma: assim, ao forte distanciamento criado pelo dispositivo de Tambours sur la digue (fábula da antiga China e técnicas de representação de marionete tomadas do bunraku) ${ }^{4}$ que "estrangeirizava" o discurso sobre o poder político e a tomada de decisão-catástrofe, se seguia a proximidade dos sofrimentos dos personagens bem contemporâneos do Caravansérail. Vindos do planeta inteiro - de Sangatte, de Cabul ou de Peshawar, de Sidney, da África ou da Rússia - eles eram encarnados por atores de todas as nacionalidades que se deslocavam exclusivamente sobre plataformas de rodinhas, metáforas e instrumentos de suas peregrinações infinitas, e deslizavam sobre um imenso palco vazio, empurrados pelos parceiros.

A cada vez se acredita que não se pode ir mais longe, de tanto que a forma (o dispositivo de jogo) parece radical e extrema na sua coerência. $E$ a cada vez, a busca, no entanto, continua sem se repetir: dupla procura a do Soleil, que se preocupa com questôes políticas e sociais, ao mesmo tempo em que se interroga sobre a essência e as possibilidades do Teatro, cujo campo é ampliado a cada um dos espetáculos.
Um espetáculo gera o outro. No final das representações dos Tambours em turnê na Austrália, Ariane Mnouchkine, que tinha encontrado naquele continente o tema de pesquisa da sua trupe para os meses seguintes, havia projetado sobre as preciosas sedas do cenário as palavras "Free refugies". Assim, os espetáculos do Soleil constituem um repertório dentro do qual eles ecoam entre si. E se a sua força e o seu brilho individual se enraízam no longo e intenso trabalho conduzido pelo grupo (8 meses para Tambours, para Les Éphémères), eles se devem também aos laços que os unem aos espetáculos de antes e de depois, ao lugar que ocupam na história desse grupo, assim como na história do Teatro. O tempo do Soleil se conjuga em três tempos: presente, passado e futuro. E os próprios filmes realizados a partir dos espetáculos (Au soleil même la nuit, Tambours, Le dernier caravansérail) fazem parte dessa "cadeia" e possibilitam compreender melhor a amplitude dessa obra teatral em curso.

\section{Ao invés do épico, a intimidade de fragmentos de vida}

Nesse percurso, Les Éphémères novamente geram surpresa, antes de suscitar por parte da crítica francesa, talvez pela primeira vez na carreira do Soleil, uma unanimidade positiva. Representada na Cartoucherie, do Natal de 2006 até a Páscoa de 2007 - antes de deixar seu porto de ancoragem em direção a Quimper, Avignon, São Paulo, Rio, Porto Alegre, Strasbourg, Taïwan. esse novo espetáculo parece ir na contra-corrente. Aliás, não se reconhece mais o espaço familiar da Cartoucherie, cuja terceira nave foi totalmente reorganizada em um dispositivo bifrontal, no qual os espectadores, colocados em cena, se vêem frente a frente ao longo das seis

4 Teatro de marionetes japonês no qual cada grande boneco é manipulado à vista do público por vários koken vestidos de preto. 
horas e meia de duração do espetáculo, sentados nas arquibancadas limitadas por parapeitos nos quais se iluminam linhas de pequenos diodos atentos e festivos que "enquadram" bustos e rostos. Desta vez, a famosa distância parece totalmente reduzida a zero! Les Éphémères são uma montagem de fragmentos de vida, em carne viva... Nela os atores lavam a louça, cozinham, comem, na cena se sente o cheiro de água sanitária ou de alecrim grelhado, um médico faz uma ecografia, um homem espreme um suco de laranja, veste-se as crianças, se faz compras, uma pequena menina aprende a andar de bicicleta...o cotidiano, em suma! $\mathrm{O}$ mais simples e o mais nu, sem a pesada e esplêndida indumentária dos Atrides, sem a convenção dos marionetes ou as máscaras da commedia dell'arte (L'Âge d'Or), sem os tchadris ${ }^{5}$ afegãos, sem a distância das quentes modulações das línguas faladas na torre de Babel do Dernier Caravansérail.

Se o espetáculo avança em novos territórios que são os do íntimo, do familiar e do banal, é porque o ajuste do foco de Ariane Mnouchkine se modificou novamente para abordar agora o individual - o "nós" através do "eu". Les Éphémères de fato dialogam com o Caravansérail, desenvolvem os temas que já despontavam por vezes no coração da grande epopéia dos humanos migradores - instantes preciosos e simples da vida passada, exílio que os separava para sempre, relaçóes de amor rompidas - o íntimo atravessando o épico, graças às narrações transmitidas pela voz gravada das testemunhas. E porque também o objeto da observação não é mais prioritariamente o estrangeiro, conforme a máxima bastante utilizada no Soleil, "Quanto mais longe se coloca o imaginário, melhor se consegue falar de si mesmo". Trata-se aqui de um único país, a França, e de franceses do tempo presente através de quatro gerações, as mesmas que hoje coexistem no Soleil. Ao invés do fôlego épico da sobrevivência que conduz o Caravansérail, é o fôlego de uma época que anima Les Éphémères, época apreendida com uma autenticidade que transcende a reprodução do cotidiano. A experiência acumulada pelo grupo e transmitida em seu seio aqui é capital; ela permite avançar, rica da cultura da precisão e do desenho cênico ensinado pelas tradiçõos das cenas orientais e da máscara. ${ }^{6}$ Enfim, a distância mínima entre o teatro e a sua matéria-prima é assumida por um modo de criação e um dispositivo específicos que evitam qualquer receoso voltar-se para si mesmo, qualquer naturalismo, qualquer voyeurismo, e permitem ver como raramente se viu: os espectadores se procuram mutuamente, ao mesmo tempo em que olham os atores, com uma atenção redobrada.

\section{"Uma narrativa íntima a trinta vozes"7}

O desafio reside desta vez no modo de escrever uma narrativa teatral a partir de momentos vividos - ao mesmo tempo muito pessoais e reciprocamente assumidos - sob o olhar de Ariane Mnouchkine, confiando nela, que se expõe no processo, tanto quanto os atores. A criação coletiva, tão praticada pelo Soleil, se aprofundou ao longo dos anos. Ela acontece aqui sem rede de proteção; a exposição de cada um é a maior possível. Trabalha-se - e o termo ensaio não convém mais; tratam-se de tentativas, experiências - sem texto, sem fábula, sem material documental outro senão a própria pessoa e, às vezes, álbuns de fotografias. Naturalmente, ao longo dessa complexa gênese, livros (Tchekhov, Jabès,

5 Véu espesso que cobre o corpo e o rosto das mulheres muçulmanas, no qual, à altura dos olhos a trama do tecido é mais aberta, de modo a poderem enxergar.

6 Os atores dos Éphémères seguiram um estágio com a dançarina coreana Kim Ri-Hae.

7 Expressão de A. Mnouchkine, entrevista em 1º de abril de 2007. 
Neruda, Proust), encontros (com uma arquivista), filmes documentários ou filmes de autor (Bergman, Kurosawa, ${ }^{8}$ Inamura, Rossellini, Scola) são chamados como guias. As "visões" que são solicitados aos atores são as de "pequenos seres humanos que descobrem que são mortais". As improvisações, que permanecem muito tempo sem fala, se apóiam na música de Jean-Jacques Lemêtre, o cúmplice de Ariane Mnouchkine, que compôs um caderno de estudos-visões musicais, todos em tonalidades menores, sobre temas definidos com ela, ao qual recorre segundo indicaçôes dadas pelos atores em exercício. O que é pedido aos atores: transparência, contenção, simplicidade, saber "tirar a própria casca”, operar com escalpelo, receber a visão do outro, procurar o concreto, ser meticuloso.

A escritura do espetáculo em processo de parto se compõe também de objetos, uma maré de objetos - móveis, bibelots, luminárias, telefones, brinquedos, louças - recuperados nas calçadas, comprados nos Emmaüs, ${ }^{9}$ encontrados nos sótãos de uns e outros. Os objetos falam dos personagens. Escolhidos e dispostos com um cuidado de diretor de arte ${ }^{10}$ pelos atores, cujo jogo consiste em criar eles mesmos o ambiente de suas improvisações, os objeto são também atores, seus parceiros: eles falam e sua linguagem é murmurante. Usados, sujos, démodés, reformados, chegam no estado em que estavam, provenientes do passado e das zonas às quais tinham sido relegados; eles trazem consigo inúmeras vidas anônimas ou identificadas, das quais foram testemunhas.
O trabalho se depura enfim, graças à imagem digital; tudo é filmado e os vídeos se transformam em cadernos de anotações e de esboços a partir dos quais os atores trabalham, assistindo e tornando a assistir as variantes para compor e guardar o seu "texto visual". Vidas privadas, improvisações coletivas, música, objetos, vídeo, são esses os instrumentos desse laboratório de escritura cênica. Sobre cerca de quatrocentas cenas, aproximadamente cinqüenta serão selecionadas. Elas consistirão os capítulos das duas "coletâneas" que constituem o espetáculo, conforme indica o programa. Concentrando a essência de várias narrativas íntimas, elas contam, como nas novelas de Tchekhov ou de Carver, "todo um grupo, uma classe, um país". ${ }^{11}$ Mais ainda, trata-se de "tecer uma tela francesa, européia e, afinal, mundial". ${ }^{12}$ Procurar o pequeno para encontrar o grande, um dos princípios heurísticos de Mnouchkine.

\section{Uma cenografia móvel e modulável: carrinhos e cinema}

No Soleil a procura do teatro é confrontada à do cinema. Este último acompanha totalmente Les Éphémères, cuja concepção começou durante as turnês, a filmagem e a montagem do filme Dernier caravansérail. ${ }^{13}$ As arquibancadas erguem-se em torno de um espaço alongado que A. Mnouchkine chama alternadamente de "mesa de autópsia, arena, lupa, Praça Navona". Embaixo da tribuna do músico, em frente a uma

8 Um dos primeiros títulos do espetáculo era Vivre, em homenagem ao filme de Kurosawa.

9 Associação que alimenta e abriga pessoas excluídas, em troca da recuperação de objetos [NT].

10 Ensemblier no original; a autora explicita que se trata de termo oriundo do vocabulário cinematográfico, utilizado por A. Mnouchkine. Nota do tradutor.

11 "Notas de trabalho de Ariane Mnouchkine", reunidas por C.-H. Bradier, 18 de abril de 2006, no programa do espetáculo.

12 Idem, 24 de abril. As citações sem referência provêm desse mesmo programa.

13 Ver "Parler du monde, parler au monde. Le cine-théâtre d'Ariane Mnouchkine", in Théâtre Aujourd'hui, n. 11, CNDP, no prelo. 
outra, sótão onde se empilham autênticas caixas de arquivos, abre-se a área de jogo, que é designada como passagem, corredor do tempo no qual deslizam os carrinhos. Descobertos durante a preparação do Caravansérail, esses carrinhos retangulares de tamanho variado rapidamente tornaram a aparecer nas improvisaçōes dos Éphémères, porque tecem juntos teatro, cinema e cotidiano, originários que são, ao mesmo tempo, dos carrinhos do filme Molière, ${ }^{14}$ da dolly que acompanhava os atores por ocasiāo da filmagem dos Tambours ${ }^{15}$ e no carrinho de lixo do cozinheiro do grupo... Uma nova forma circular, no entanto, se impõe rapidamente. Esferas de mundos íntimos, esses carrinhos avançam completamente carregados de personagens, móveis e objetos. Atapetados, eletrificados, eles entram e atravessam, girando sem fim sobre si mesmos, estranho ballet bem ajustado, ao longo do corredor no chão cinzento, oferecendo-se ao público na totalidade de seu volume. "Puxadores" felinos, atentos, inquietos, delicados, dominam a velocidade e o ritmo dos deslocamentos, desvelando as ações dos personagens feitos por seus companheiros. E a ação se desenrola em planossequiência muito longos, improváveis no cinema, já que se pode perceber num mesmo olhar o interior de cada quarto completamente mobiliado, mas sem parede, e o avesso do cenário.

\section{Um dispositivo de visão e rememoração}

Sem nunca perder de vista os outros espectadores que constituem o pano de fundo, o que evita qualquer identificação, assiste-se então a Paixões humanas, em suas múltiplas estações. Sua forma - jogo, coreografia, ritmo, melodia e escuta; esta última ligando os atores e o músico que toca para cada um deles diversos instrumentos, superpondo-os à música gravada que ele mesmo aciona e controla - suscita atenção e emoção, tanto quanto o trabalho dos atores que fazem vários papéis e são, todos, cativantes. Esse teatro em imagens, em movimento constante, com palavras contadas, é um teatro da memória, musical, gestual, uma espécie de cinema atlético e ao vivo, sem outra tela senão esses palcos giratórios. Closes reiterados sobre os personagens (atores e objetos), detalhados pelas cirandas desse dispositivo cinético, planos largos quando os carrinhos desaparecem sob as cortinas que, em cada extremidade do corredor, inflam suas dobras cinzentas como no teatro Nô. Cada objeto suscita um reconhecimento surpreso; os espectadores se falam, balbuciam, choram, riem. Porque o lento movimento giratório, repetitivo e a aparição das visôes dos personagens em flash back sobre os carrinhos, provocam neles reminiscências fulminantes e os convidam a tomar o tempo de rememorar seus próprios acontecimentos fundadores, ao lado das histórias dos seres tornados fictícios, que o trabalho teatral comum soube esculpir, ligar e que eles acompanham, de uma entrada à outra. Pausas freqüentes, nas quais o espaço vazio só é povoado de maneira sonora, reforçam essa proposta de trabalho ativo sobre si mesmo.

E o teatro pode fazer tudo, ousar tudo, tudo, como o cinema, do qual ele soube e pôde - transformando seu palco em estúdio de cinema para a realização de filmes de seus últimos espetáculos - assimilar e transpor as técnicas. A ponto de descobrir como mostrar uma mulher velha, suja, louca, doente, um acidente de trânsito mortal ou a revolta de um oficial de justiça diante da situação de um casal super endividado... Ou como fazer intervir crianças, essas "pequenas pessoas" frágeis e fortes, que estão em toda parte nesse espetáculo - nosso passado e nosso futuro. "Um dia inteiro, ainda é muito curto!”, escreve uma espectadora, numa dessas

14 1977, cenários por G.-C. François.

15 Em 2001. 
inúmeras cartas que o público dirige regularmente ao Soleil. Bem poderíamos, com efeito, permanecer às margens desse rio-tempo, rolando, lúcidos, com os atores, nossos próprios carrinhos, quartos da infância, dos pais, das mães tão presentes, dos filhos ou netos. Les Éphémères são um ritual de evocação coletiva daquilo que intimamente teceu o presente de cada um. Nele o Soleil experimenta um compromisso novo, urgente: focalizar-se no homem comum, grão de areia que a globalização exila longe de si mesmo, tentar compreendê-lo sem as velas do narcisismo egocentrado, dos problemas genéricos ou das ideologias. De onde viemos, quem somos? Em um período de transformações rápidas, no qual a amnésia é um dos componentes de nossa vida, a busca do fio essencial que religa os seres humanos ao mundo é decididamente política. E assim como em As sete margens do Rio Ota do canadense Lepage, em Wielopole, Wielopole do polonês Kantor, aqui ela não negligencia a História, e a Resistência é evocada em cinco episódios, fragmentos de um espetáculo sonhado que Mnouchkine (ainda?) não realizou. No intervalo, pode-se beber o tchaï cuja venda é destinada a sustentar um teatro afegão nascido de um estágio arriscado que o Soleil coordenou em Cabul, ${ }^{16}$ em 2006. Esse teatro leva o nome daquele que o apadrinha; o Petit Soleil já veio à França, com a ajuda dos espectadores fiéis que possibilitaram o fechamento do orçamento. Foi sob o olhar desse nascente teatro distante que Les Éphémères começaram a ver despontar o dia.

16 A projeção de um filme sobre esse estágio produzido pela emissora ARTE e realizado por um dos atores do Soleil, Duccio Bellugi-Vanuccini, encerrou a primeira série de representaçôes dos Éphémères na Cartoucherie. 